\title{
Progesterone Receptor Positive by Immunohistochemistry 41-50 Percent
}

National Cancer Institute

\section{Source}

National Cancer Institute. Progesterone Receptor Positive by Immunohistochemistry 41 -

50 Percent. NCl Thesaurus. Code C141452.

An immunohistochemical staining finding indicating that 41-50 percent of the cells in a tissue sample are expressing progesterone receptor. 